UDC 81

DOI https://doi.org/10.32838/2663-6069/2020.3-2/11

\author{
Mammadova Gunay \\ Ganja State University
}

\title{
DERIVATIVE CHARACTERISTICS OF INDEPENDENT PREFIXES IN THE AZERBAIJANI AND ENGLISH LANGUAGES
}

The purpose of the article is to consider some aspects of the derivative characteristics of independent prefixes in the Azerbaijani and English languages, where the formation of prefixes in different languages is due to the ever-increasing intensity of information activity.

Research methods. In this study, aspects of diachrony include moments such as the occurrence of the annulment value in prefixes, as well as the allocation of the generative when forming verbs and nouns with the annulment value.

In the study and generalization of the material, methods of component analysis, a systematic description of the units under study, a comparative analysis of independent prefixes, and also a method of description and quantitative calculation were used. The work widely uses the technique of observing, comparing and summarizing the units under study.

Novelty. For the first time in a domestic study in the field of studying the characteristics of independent prefixes, it is noted that information activity requires the appearance of new concepts, where the need for generating new words to express these concepts increases. Since existing words cannot express new concepts at all, there is a need for word formation tools to convey these concepts. One of the important directions in the formation of these tools is the tendency to attach independent meaningful words.

Conclusions. Summing up the study, it is noted that the formation of prefix elements is universal in the initial information phase, where there is a tendency to attach. In this sense, the formation of prefix elements has become a common requirement in all languages with inclinations. Thus, the formation of prefixes in the English language has acquired the character of internal legitimacy as one of the analytically flexible structural languages.

Unique prefixes that affect the formation of prefixes are also formed in the Azerbaijani language. The difference is that since English is analytically flexible, the prefix in this language has become a constant sign, and the formation of prefix elements in the Azerbaijani language has been limited to the formation of suffixes. However, based on the intensity of information in the Azerbaijani language, the language itself can form new prefix elements.

Key words: prefix, suffixes, aglutinative languages, analytic-flexive languages, derivative elements.

The intensification of information led to the activation of the affixation process in language. In the process of activation of information intensity, the function of prefixses began to increase. As a result, the prefixes attached to the beginning of the word also became independent. Because of analytic-flexive structure of English language, the network of independent prefixes in this language has grown and expanded. As the prefixes at the outset expanded their functionality to become a permanent process, the language also had the potential to serve as a means of increasing their potential. Although there was a process of independence of prefixses timely in Azerbaijan language, this process have been slowed down due to development of suffixses and prefix variants began to be used as a special derivative at the beginning of word roots. But, of course, as in nature, no element is lost in the language, it continues its footsteps in one way or another. In this sense, as there were prefixed elements that could be attached to certain words in the early stages, later even certain phonomorphological constituents, characterized by their word independence, acquired derivative functionality as prefixed units. As independent variants of the prefix content are characterized by their own concepts in both languages, linguistic studies have developed the idea that these means are derived from independent words. Also, the fact that the prefixed constituents added to the beginning have an independent meaning has prompted the idea that compound words are more primitive 
in terms of origin and formation. Salim Jafarov writes about formation processes of affixses: "In the old days of our language, the process of making complex words from simple words has long played important role. Later, morphological processes were formed by the transformation to affix of a word that is used in the composition of complex word [3, p. 161]. Based on the idea of the formation of affixses from independent words, we can conclude that when the first constituents of complex structures were formed, the prefixed elements formed, while the second part formed the suffix elements. Both morphological elements occur in both analytic-flexive languages and aglunative languages. The difference is that, as the prefixes in the analytic-flexive languages are activated, suffixses are activated in aglunative languages and gain systematic character. The role of syntactic isomorphic models in the formation of affixses is also confirmed by research in this area $[1$, p. $73-75$; 9 , p. 92; 14, p. 27-29]. As one of the analytic-flexive languages, expanded perspectives of prefixes in English and served to form both universal words and terminological units. These perspectives have reached such a level of development that they are spreading in a wider environment and even becoming an international means of word formation $[5$, p. 33-35; 10, p. 77-72; 17, p. 3-7].

The goal here is to discover the interdisciplinary universals and their derivative features. At the same time, it is to prove that the prepositional character derivatives available in the Azerbaijani language are not accidental and are a traditional continuation of the initial vocabulary elements. The authors refer to the prefixes used in English, suggesting that there is no clear rule for their use. At the same time, it is thought that the prefixes form verbs with noun and adjectives, and joining the verbs are thought to form words based on the parts of the speech [2, p. 23-35; 13, p. 125-130; 16, p. 69, 95]. Although the English prefixes serve as the illustrator in the word-processing process, their semantic environments are also considered to have been completely eradicated. And when you join it to the beginning of the word, that semantic environment becomes even more vibrant and becomes a means of expression of an independent concept. Therefore, in English-based sources, the affixes are systematized based on the meanings they have and the words they occur. As one of the analytic-flextive languages, the English language does not have a series of figurative systems in accordance with the aglunative languages. But instead, rich derivative tools for wordformation in English were formed. A very important part of these derivatives also consists of prefixes used in the preposition position.

anti-, de-, dis-, down-, extra-, hu-, per-, il-, im-, in-, ir-, inter-, mega-, mid-, mis-, non-, over-, out-, post-, pre-, pro-, re-, semi-, sub-, super-, tele-, trans-, netra-, under-, up-, a-, an-, ak-, ante-, auto-, urcum-, co-, com-, con-, contra-, contro-, en-, ex-, hebero-, homo-, homeo-, hyper-, tutra-, intro-, macro-, omni-, past-, sum-, syn-, trans-, tri-, uni-, one-, single-, away-, fron-, para-, post-, semi-, super-, therm-, thermo-, aero-, auto-, counter-, epi-, maxsi-, meso-, meta-, mini-, mono-, asto-, multi-, supra-, tetra-, trams-, netra-, xeno-, ab-, ad-, af-, an-, as-, bi-, dactil-, deka-, deci-, dem(o)-, dermo-, derma-, dermat-, elect-, breto-, stomo-, spero-, fachy-, stilo-, sthno-, ergo-, eroto-, enceptal va s. [4; 14].

Thus, the English prefixes can be summarized in the following classification for their meaning:

\section{Denial prefixes.}

In English, denial prefixes are added to the words and express the opposite or antonym meaning. Denial prefixes are mainly joined to adjectives. In the sentence, such words mean no, not, it is not accordance with denial conception. The prefixes for denial are: in-, im-, il-, ir-, a-, non-, dis-, mis-. The meaning of denying these prefixes can be seen in the following examples:

I am unable to do this; It's impossible!

The prefix $u n$-is added to the words beginning with the vowel as a rule. However, in some cases, this prefix is also added to the words beginning with the consonant: unable (Not to be in power, incapable to help, helpless); unhelpful (useless); unknown (mysterious); uncomfortable (worried, uneasy); unfinished (incomplete).

The prefix in- is added to the words beginning with the vowel and consonant, except $-i$ - and $-u$ - vowels: inaccurate (mistaken, inexact), inaction (inactivity, inertness), inorganic (inorganic), inactivity (passive), incapable (unskilful, dull), incessant (without a break).

The prefix $\mathrm{im}^{-}$is only added to the words beginning with $-m$ - and -p-consonants: immoral (dissolute), immorality (profligacy, libertinage), immortal (eternal, everlasting), imparity (inequality, intangible, unknown), impartible (indivisible, whole), impasse (desperate situation), impendent (inevitable, inescapable).

The prefix $i l$ - is only added to the words beginning with -l- consonant: illiteracy (lack of education), illegal (unlawful), illimitable (limitless), illogicallity (lack of logic).

The prefix $i r$-is only added to the words beginning with $-r$ - consonant: irreverent (disrespectable), 
irrelevant (incompatible), irreversible (immutable), irresistible (inevitable, flatly, undeniable).

The prefix $a$-combines words that begin with a consonant and denotes an appropriate denial: avate (to diminish, to reduce), aberrant (who made the mistake), amoral (unethical).

The prefix non- denotes denial by joining words beginning with a consonant or a vowel: nonconformity (to be disagree), non-payment (do not give payment), nonchalance (lack of difference, nondifference); nojhalant (careless, insolent); non-attendance (nonpresence, absence).

The prefix dis- include words that are inversion of behavior and quality by joining words with consonant or vowel origin: dispore (refutation), disslut (disagreement), dissimulate (to hide, play the hypocrite), dissosial (unsociable, disconnected); disagree (do not be agree, to discuss), disaffrim (to deny), disaccord (disagreement, conflict).

The prefix mis- is added to the words beginning a vowel or consonant and notifies not convincing, untruth meanings: misdealing (wrong move, unethical behavior), misdirect (send to the wrong address), misinform (confuse, mislead), misinterpret (misinterpret), misapprehend (misunderstandings).

\section{Prefixes denoting the repetition and coherence of the action.}

In English, re- and co-prefixes are used to refer to the repetition of the movement:

The re-prefix joins the following verbs in accordance with the function of repeating the movement: realing (reappear), cebirth (revival); reconsider (review, review again); colectinism (collectivity), collaboration (collaborate, work together), colletable (able to be collect), collected (gathered), coincide (overlap, fit).

3. Prefixes of past, occurrence, expiration, and events.

In English, the prefixes $e x$ - and $d e$ - are added to the beginning of the words to express these concepts.

The ex-prefix is attached to the words and expresses an appropriate understanding of the past, the things, and the stories: exportation (to send abroad), ex-president (old president), exhaustible (ended), exhaustive (diminishinh, ending), ex-member (old member), extinct (extinct, expired, obsolete).

The prefix $d e$ - is joined beginning of word as derivative mean and give expired, outdated, backward characteristic meaning: deprave (to spoil, to destroy), depression (to lose courage), degenerate (sexually disturbed), degradation (decline, to grow poorer), dehidration (calcination), deject (oppression, enslavement).
4. Prefixes expressing superiority, excess, plurality, abundance, deficiency and belonging.

In English language, these are expressed by such words over-, under-, sub- prepositive elements. For example, the over-prefix is attached to the beginning of the word and serves to express the concept of superiority, plurality, excess, abundance: overact (play better, play more, overstep); over-active (high activated); overbear (to come out strong, to win); overcharge (high charge); overcrowd (excessive, to fill, to shoot, to collect, to assemble).

Under- prefix has the function of expressing the appropriate antonym as opposite of over-prefix: undervid (lower the price), underfed (not eaten), underfed (don't eat enough); undermine (to dig under).

The sub- prefix is used in terms of relevance, to be included, to be divided in the such following words: subdivide (to divide, separate); subdual (to obey); subjection (dependence, submission); subside (to decrease, to settle, to quiet, to slow); subtitre (caption), suburban (local), substandard (non-standard), submarine (underwater).

\section{Prefixes denoting excessiveness, width, cluster,} low.

The English language uses the prefixes super-, hyper-, hypo-, which are used in the word processor for this meaning group.

In the presence of the super-prefix, it is used at the beginning of the words to mean excessive, greater, and more preferable: supercool (too cold); superfine (the best kind, the finest, the most elegant); superfluous (excessively); superheat (too heat); superhuman (preternatural); superiority (advantage); superlative (predominance, odds, excellence); supermarket (great self-service grocery store); supernal (amazing, fascinating).

Hyper- prefix also refers to the beginning of the words and expresses the meaning of a more powerful, superior, greater understanding: hyperactiv (high activitity); huperbolical (exaggerated, inflated); hyperbolize (to increase, grow); hypersensitive (high sensitivity).

The hypo- prefix is used to denote the down meaning as opposed to the hyper-prefix: hypodermic (subcutaneous), hypoactivity (low activity), hypochondratic (suffering fromunochondria) and etc.

6. Prefixes used to express the opposite meaning in scientific terminology.

The prefixes included in this sense group are comprised of ultra- and intra-word formation means. The words that ultra-prefix is attached mean off limits, extreme and etc. For example: ultramodern 
(extremely modern), ultrasound (ultrasonic frequencied sounds), ultramundane (located within the solar system); ultrasonic (more loud, more fast), ultrafost (the fastest).

In contrast, the prefix infra- is used to mean lowerness: infrastructure (lowerstructures), infrasonic (lower tone); infraspesific (low type), infraction (disruption, failure).

7. Antonym prefixes used to create before-after meaningful words.

The prefixes included in this meaning group are pre- and post- components.

The prefix pre- is used in the formation of words that mean ahead and in front: precursory (ahead, before), predate (to be ahead, to come before); preclusion (prevent, warn), precede (to be ahead, to come first); precedence (first place).

The prefix post-, by contrast, participates in the formation of words that express later, subsequent meanings: postbellum (belonging to the post-war period), posterior (next, succeeding, following, behind); postmeridiem (after noon).

8. Prefixes used to express such meanings "between, interval, over".

This group includes inter-, intra-, and transprefixes.

The inter- prefix is used at the beginning of the following words, meaning to be in interval of something: intermediary (mediator, negatiator); intermixture (alloy, mixture); interpersonal (among people); interrelation (mutual relation); intersect (cross), interstellar (among stars), interspesitic (among species).

The intra- prefix is used to connect words, to express their understanding of the inside and the boundaries of something: intravuclear (inside nuclear), intrapenous (inside vein); intramuscular (inside muscle), intraday (during the day).

The trans- prefix participates in the formation of words with the meaning of to be passed: transit (to move, to jump), transitpoint (transition rate), transition (change from one place to another); transitional (intermediate), transoceanic (on the other side of the ocean).

9. Prefixes used to convey forward, back, opposite meanings.

This group of meanings include pro-, retroand anti- prefixes.

The pro- prefix is often used to denote the concept of moving forward, or belonging to or supporting: progress (development), prognosis (to tell in advance), progression (moving, progress, develop), progressive (advanced, progressive).
Retro- prefix joins the beginning of the word and participates in the formation of words that express their back and past meanings: retrograde (reverse, defiant, subversive, moving backwards, back); retrogress (to decline, to worsen); retrospect (a look at the past), retrospection (to refer to the past, to reflect on the past); retroaet (to go back).

Anti-prefix is used as an antonym of the pro-prefix with the opposite meaning: antibody, anticyclone (opposite cyclon), antiaircraft (against air attack, against air defense); antiquated (old, obsolete, ancient); antiquity (obsolote, ancient), antisocial (socially isolated, unreliable).

10. Prefixes for denoting meanings of beyond the boundaries, the quality advantage from the inside to the environment.

Here includes extra- and out- prefixes. Extraprefix is used to form words with to be better, to have the advantage meanings: extraction (to extract, to obtain); extraordinary (non-ordinary), extractive (extractable, obtainable).

In the words corrected with the use of the outprefix, the terms are defined as outsider and outward: outsider (stranger); outskirst (vibration, edge, environment); outward (appearence); outstep (to step over).

\section{Prefixes used to denote half meaning.}

This group includes hemi-, semi- and demiprefixes. The prefix hemi- includes Greek originally. When it is joined words, it creates new units that are incomplete and express semi-concepts: hemisphere (half sphere), hemistich (half stich), hemicycle (half cycle).

The prefix semi-include Latin language originally. It also creates half and incomplete meaningful words: semi-basement (half basement), semi-circle (half circle); semifinal (half final), semitone (half tone).

The prefix demi- include French language according to its origin. It also joines to the words and creates half meaning: demi-monde (twilight), demitone (half tone), demi-lance (half lance).

12. Prefixes used to express unity - smallness meanings.

This group includes mono- and multi- prefixes. The mono- prefix is used to express singularity, unity: monomial (single); monolingual (single-handed), monocracy (autocracy); monobasic (monolithic), monolith (whole).

With the joining of multi- prefix to the words the new words are formed and express many, various meanings: multifarious (various, different), multiform (versatile, diverse); multilateral (versatile); multilingual (polyglot), multiracial (multinational). 


\section{Prefixes used to express concepts of decline, grinding, growth.}

This meaning group includes mini-, microand macro- prefixes. The mini-prefix is used to denote a reduction andsmallness: miniature (small); minimal (smallest), minimus (smallest); minimize (to decrease).

With the presence of the micro- prefix, words are formed that express a very small size: micrograph (small picture); microfilm (short film), micromotor (small motor), microware (short ware).

In contrast, the macro- prefix is used to form words that have a voluminous meaning: macrocosm (world, universe), macrobiosis (long life), macroeconomic (big economy).

\section{Prefixes used to express the concept of coverage.}

This meaning group includes en- and em-prefixes. $E n$ - and $\mathrm{em}$ - prefixes differ from other English prefixes because of their functionality. These prefixes can also change the part of the speech to which it belongs by joining words. $E n$ - and $\mathrm{em}$ - prefixes can form verbs by joining more nouns and adjectives. One of the enand $\mathrm{em}$ - prefixes is the phonetic variant of the other. The prefix en-usually turns out to be the em-position in the position preceding the consonant of $\mathrm{p}$ : enlarge (to expand), enlarged (expanded), eneiven (revive, reinforce, strengthen); emotional (excited, sensitive); emplacement (location), empower (to authorize).

The richness of the English prefixes indicates that there is a wide range of new word-formation capabilities in this language. Their comparison with the prepositional language derivatives of the Azerbaijani language gives a serious impetus to the identification of the functional nature of these types of word-formation tools in the Azerbaijani language.

It is said that "There is no prefix in Azerbaijani language. In the past, many of the words in Arabic and Persian originated were used in our language as well as their prefixes. Now those prefixes have been replaced by own national affixes of the Azerbaijani language [17, p. 58]. The idea that there are no prefixes in the Azerbaijani language is not true. Because it has happened, it keeps its footsteps, and continues its traditions in one way or another, even with the increased information intensity. The results of the comparative analysis show that the prefixes in the Azerbaijani language did not consist only of the elements that form the adjectives' rates. These elements are generally formed as derivative agents of reductive nature. These prefixed elements, beginning with the word, served to intensify the meaning according to their reductive nature and to create a "degree of intensity" as shown in the linguistic literature. Such derivatives in the Azerbaijani language are not limited.

The expansion of informatics in the modern world has an important impact on the development of prefix derivativeness. This does not slow down the word process in the Azerbaijani language by means of a series of suffixes, on the contrary, the development of both methods has a positive impact on reviving the internal potential of the language and enhancing its lexicalsemantic capabilities.

Modern prefixes. The name of the modern prefixes is actually a condition. The characteristic feature of these prefixes is that they can be separated from the word and serve as an independent meaning. That is why they have not undergone the process of affixation. The similar feature of independent type prefixes with English prefixes is that they have a certain meaning potentials in both languages. The difference is that the prepositional units in the Azerbaijani language are only carry prefix function at the beginning of the word. English prefixes are considered as units that are already represented as a prefix. The tendency of prefixed units in the Azerbaijani language to express affixation suggests that not one or more words are corrected in their approach. Examples include: with the word "ac" (hungry): acgöz, acgözlülük (glutton), acqarma, ac-yalavac (hungry); with the word "ala" (motley): ala toran (twilight), alaqarın (half-starved), alabula (gaycoloured), ala-çiy (half-cooked), ala-nəm (half wet), alababat (half good); with the word "tay" (match): tay-qulaq (one-eared); taybuynuz (onehorned), tayqıç (one-legged), tayqulp (tankard); with the word "oyri" (bend): oyri-dimdik (hook-billed), ayriburun (hook-nosed); With the word "tək" (single): təklülə (single-barelled), təkqanad (one-winged), təkqat (one-holded) etc.

Prefixes of foreign origin. Foreign prefixes have been introduced into the Azerbaijani language with their vocabulary composition. Therefore, those prefixes are usually used in the context of the word that they were taken from. In some cases, it is also possible that these derivatives are included in the words in the Azerbaijani language. This happens when these affixes are intensified and popularized in the Azerbaijani language for their derivative function. At the same time, some of the prefixes of foreign origin were replaced by suffix equivalents in Azerbaijani language.

In the Azerbaijani language, the prefixes that include Russian and Europe languages are used along with incoming words: avia-: aviabomb (aviation bomb), aviamodel (aircraft model); auto-autobase (car base), 
autobenzine (car benzine); bio-biogenesis (biological origin), bioelectric (biological electric) and etc.

Intensified forms of this type of prefixes can also be added to the words in the Azerbaijani language: aviaaviation, avia transportation; auto- autochthonous; anti-anti-crisis, anticism and etc.

Conclusions. From the comparisons and the analyzed examples it is clear that, despite the existence of interdisciplinarstructural differences, they also have the principle of informatics. The emergence of inter-disciplinary structural differences is related to the possibility of expression of information specific to different language families and groups. While these possibilities were universal in the early stages, the structure then began to differentiate according to specific features.

\section{References:}

1. Баскаков Н. А. Историко-типологическая морфология тюркских языков. Москва : Институт языкознания АН СССР, 1979. $273 \mathrm{c.}$

2. Бурлакова В. В., Иванова И. П., Почепцов Г. Г. Теоретическая грамматика современного английского языка. Москва : Высшая школа, 1981. 285 с.

3. Cafarov S. Muasir Azerbaycan Dili. Baku : Maarif, 1970. 235 p.

4. 35 Common prefix in English. URL: https://www.thoughtco.com/common-prefixes-in-english-1692724.

5. Даниленко В. П. Русская терминология. Опыт лингвистического описания. Москва : Наука, 1977. $295 \mathrm{c}$

6. Drmirçizade E. Azerbaycan Dilinin Uslubiyyatı. Baku : Azerbaycan Dovlet Tedris Edebiyyatı Nəşriyyatı, 1962. $271 \mathrm{p}$.

7. Hüseynzade M. Müasir Azərbaycan Dili. Bak1 : Azərtədris nəşr, 1963. 271 p.

8. Xalilov B. Muasir Azerbaycan Dilinin Morfologiyasi. Baku : Elm, 2007. 280 p.

9. Корнилов Г. Е. Имитативы в чувашском языке. Чебоксары : Чувашское книжное издательство, 1984. $184 \mathrm{c}$

10. Головин Б. Н. Введение в языкознание. Москва : Высшая школа, 1983. 324 с.

11. Mammadli N. Azerbaycan Dilinde Alınma Terminler. Baku : Elm ve Tehsil, 2017. 488 p.

12. Panahlı S. İngilis Dilinde Prefiksler. URL: www.kültürevreni.com.

13. Prefixes. URL: https://dictionary.cambridge.org/grammar/british-grammar/prefixes.

14. Prefixes. Префиксы или приставки в английском языке. URL: https://grammarway.com/ru/prefixes.

15. Рамстедт Г. И. Введение в алтайское языкознание. Москва : Изд-во Иностранной литературы, 1957. $253 \mathrm{c}$

16. Смирницский А. И. Морфология английского языка. Москва : Изд-во литературы на иностранных языках, 1959. 440 с.

17. Юшманов Н. В. Элементы международной терминологии. Москва : Наука, 1968. 70 с.

18. Yusifov M., Adilov R. Azerbaycan Dili. Gandja : İrşad Merkezi, 1996. 139 p.

19. Word structure: Derivation. URL: http://www.englicious.org/lesson/word-structure/word-structurederivation.

\section{МамМадОВа ГюНай. ПОХІДНІ ХАРАКТЕРИСТИКИ НЕЗАЛЕЖНИХ ПРЕФІКСІВ В АЗЕРБАЙДЖАНСЬКІЙ ТА АНГЛІЙСЬКІЙ МОВАХ}

Мета статті - розглянути деякі аспекти похідних характеристик незалежних префіксів в азербайджанській та англійській мовах, у яких формування префіксів відбувається через постійно зростаючу інтенсивність інформачійної активності.

Методи дослідження. У статті до аспектів діахронії віднесено такі моменти, як виникнення значення анулячії в префіксах, а також виділення генеративу під час утворення дієслів та іменників зі значенням анулящії.

Під час вивчення й узагальнення матеріалу застосовувалися методи компонентного аналізу, системного опису досліджуваних одиниць, порівняльний аналіз незалежних префіксів, а також метод опису та кількісного підрахунку. У роботі широко використовується прийом спостереження, зіставлення й узагальнення досліджуваних одиниць.

Новизна. Уперше у вітчизняній науці стосовно вивчення характеристик незалежних префіксів зазначається, що інформаційна активність вимагає появи нових кониепиій, коли зростає необхідність генерування нових слів для вираження циих концепцій. Оскільки наявні слова не можуть виражати нові поняття взагалі, є потреба в інструментах словотворення для передачі иих понять. Одним із важливих напрямів у формуванні иих інструментів є тенденція до приєднання самостійних значущих слів. 
Висновки. За результатами дослідження зазначається, що формування префіксних елементів є універсальним на початковій інформачійній фазі, коли спостерігається тенденція до приєднання. У иьому сенсі формування префіксних елементів стало загальною вимогою в усіх мовах із нахилами. Таким чином, формування префіксів в англійській мові набуло характеру внутрішньої легітимності як в одній з аналітично гнучких структурних мов.

Унікальні префікси, щовпливаютьна формування префіксів, такожутворюютьсявазербайджсанській мові. Різниия полягає в тому, що, оскільки англійська мова є аналітично гнучкою, префікс у ній став постійним знаком, а формування префіксних елементів в азербайджанській мові було обмежене формуванням суфіксів. Однак, з огляду на інтенсивність інформачії азербайджсанською мовою, сама мова може формувати нові префіксні елементи.

Ключові слова: префікс, суфікси, аглютинативне мовлення, аналітично гнучкі мови, похідні елементи. 